\section{Lembaran Sejarah}

\title{
Auto-activity: Decolonization and the Politics of Knowledge in Early Postwar Indonesia, ca.1920-1955*
}

\author{
SEBASTIAAN BROERE \\ University of Amsterdam \\ Email: s.c.j.r.broere@uva.nl
}

\begin{abstract}
This article presents a history of decolonization and its politics of knowledge by examining rural reconstruction programs in the first decade of Indonesian independence. It traces the roots of Indonesia's first two agricultural development schemes to late-colonial criticism of state policy. In these criticisms and schemes, "auto-activity" emerged as a key concept. This paper argues that in the writings of planners and politicians, "auto-activity" facilitated the process of decolonization in various ways. The notion of auto-activity affirmed Indonesian know-how over foreign technical assistance; those who developed it would overcome subjective legacies of colonial subjugation; it encouraged the institutionalization of a benevolent state that helped rural communities to help themselves, and would thus contribute to the materialization of a fair and just society. This article concludes that despite these practices of decolonization, programs of "auto-activity" also opened up possibilities to overrule farmers's individual choices in new ways.
\end{abstract}

\begin{abstract}
Abstrak
Artikel ini membahas sejarah dekolonisasi dan politik pengetahuan dengan melihat secara mendalam program pembangunan pedesaan pada dekade pertama setelah kemerdekaan. Artikel ini menemukan bahwa dua program pembangunan pertanian pertama Indonesia berakar pada kritik terhadap kebijakan negara kolonial akhir. Kritik dan program pembangunan ini muncul dari konsep mengenai 'auto-aktiviteit.' Artikel berargumen bahwa konsep 'auto-aktiviteit' yang muncul dalam tulisan para perencana dan politisi membantu proses dekolonisasi dengan beragam cara. Ide autoaktiviteit mengedepankan pengetahuan Indonesia dibandingkan pengetahuan luar yang masuk lewat bantuan asing. Pengembangannya juga membantu menghilangkan prasangka-prasangka kolonial yang telah diwariskan. Ide 'auto-aktiviteit' juga mendorong pelembagaan sebuah negara bajik yang membantu masyarakat pedesaan untuk bisa mandiri, dan sehingga berperan utama dalam mewujudkan masyarakat yang adil dan makmur. Tetapi artikel ini juga menyimpulkan bahwa walaupun ada usaha-usaha dekolonisasi ini, program-program auto-aktiviteit juga mengakibatkan peluruhan hak individual petani untuk bisa memutuskan berdasarkan kepentingan pribadinya dengan diganti oleh program-program kolektif.
\end{abstract}

\section{Keywords:}

Decolonization; Indonesian Rural reconstruction; Kasimo Plan; Knowledge; Rentjana Kesedjahteraan Istimewa (RKI); State-society relations; Village Education Centers (BPMD)

\section{Kata Kunci:}

Badan

Pemberdajaan

Masjarakat dan

Desa (BPMD);

Kasimo Plan;

Rekonstruksi pertanian Indonesia; pengetahuan; Rentjana Kesedjahteraan Istimewa (RKI); state-society relations

*) This paper is a condensed version of a chapter from the author's draft dissertation, A Matter of Life and Death: Agriculture and the Politics of Knowledge in Postwar Indonesia (1945-1967). It examines the history of agricultural development in Sukarno-era Indonesia. 
At the Food and Agricultural Organization's (FAO) seventh conference in Rome in 1953, Director-General Norris E. Dodd deplored the lack of commitment by governments to agricultural extension in developing countries. Like education and research, agricultural extension provided a key means to intensify food-growing practices, and thus to the FAO's efforts to reduce malnutrition and global food shortages. ${ }^{1} \mathrm{He}$ argued technical assistance and information would be to no avail if not utilized by the people themselves, for "only the people who farm the land and fish the waters can produce more food" (Dodd, cited in Staples, 2000: 403). Instead of trying to expand arable land, governments should direct their attention to increasing yields per hectare.

Indonesia's application for FAO membership had been initiated by the postwar Dutch government. It was officially approved on 28 November 1949, less than a month before the transfer of sovereignty to Indonesia. In 1953 an Indonesian delegation attended the Rome conference, where it argued that Dodd's standpoint did not fully address the issue. The leader of the delegation, Soekardjo Wirjopranoto, emphasized that the People's Agricultural Service had replaced the "old system (personal contact) with a new system which pursued community improvement in the broadest sense (mass education)". ${ }^{2}$ By means of its Balai Pendidikan Masjarakat Desa (Village Education Centers - BPMD), the extension service encouraged peasants to use selected seeds and green fertilizers like manure and Crotalaria plants. Villagers were also encouraged to join forces and establish cooperative societies. At the FAO regional conference in Bangalore, India, earlier that year, Indonesia's delegation had delivered a similar message, stating that "it is the peasant who actually realizes production ideals."

This article delves into the history of Indonesia's decolonization and its politics of knowledge by examining some of the ideological, political and epistemic considerations that informed representations and practices of rural reconstruction in the first decade of independence. The vision behind Indonesia's first two development schemes-Plan Kasimo (1947) and Rentjana Kesedjahteraan Istimewa (1950, Special Prosperity Plan - RKI) was presented by Sadjarwo, who headed the planning division of the Ministry of Agriculture. The RKI, he stated in 1951, "centers first and foremost on psychological factors, to move the people towards auto-activity in implementing the plan

1) 'Laporan Delegasi Indonesia ke-Sidang ke-VII dari Konferensi FAO Roma, 23 November-11 Desember 1953', p. 13, Arsip Nasional Republik Indonesia (ANRI), Jakarta, Arsip Kabinet Presiden 1950-1959, No. 494. See (Pernet \& Forclaz, 2019) for an overview of recent scholarship on the FAO.

2) 'Laporan Delegasi Indonesia ke-Sidang ke-VII dari Konferensi FAO Roma', p. 13.

3) 'Laporan Delegasi Indonesia ke Rapat Regional FAO untuk Asia dan Timur Djauh bertempat di Bangalore, India, pada tanggal 27 Djuli-5 Augustus 1953', p. 4, ANRI, Arsip Sekretaris Negara Kabinet Perdana Menteri RI Tahun 1950-1959, jilid I, No. 2711. 
and to make the village community more dynamic." ${ }^{\prime 4}$ The administrator, who was a leading member of the Barisan Tani Indonesia (Indonesian Peasants Front - BTI), did not deny the value of scientific and technological innovation, yet maintained that Indonesia would benefit most from nurturing peasants and fostering their communities. According to Teko Sumodiwirjo (1953: 23), one of the architects of the Kasimo Plan and the BPMD, the centers did not aim to increase production as such, but to "mobilize interests and open people's hearts so that with additional production farmers could improve their livelihoods".

The Kasimo Plan, and its successor, fit a type of development that recent scholarship has characterized as "low modern" (Gilbert, 2003; Unger, 2015; Fischer-Tiné, 2018). In Seeing like a State, James C. Scott (1998: 8990) famously applied the term "high modernism" to a set of authoritarian improvement schemes that placed high value on techno-scientific expertise as a means to increase production, rationalize social order, and satisfy human needs. What distinguishes low modernist schemes from the developmental strategy discussed by Scott is a concern for socio-economic organization, cultural modernization, and rural well-being, rather than a narrow focus on techno-scientific intervention and output increases. Low-modern approaches emphasize mutual trust between farmers and agricultural extension workers. It also identifies peasant participation as crucial to rural reconstruction, values local knowledge and peasant skills, and cheers simple and inexpensive interventions as a pathway to rural welfare. By emphasizing the need for lowmodernist development, the Kasimo Plan and the postwar RKI continued pre-war programs of rural reconstruction, though not exclusively those of the colonial state (Van der Eng, 1996; Moon, 2007). Instead, Indonesian planners drew freely from, in the words of Subir Sinha (2008: 59), a "transnational development regime" that comprised a widely dispersed field of state and non-state actors, institutions, and knowledge, all concerned with the problem of rural poverty.

In the 1950s and 1960s states and international development agencies gradually abandoned locally-sensitive and low-modernist approaches in favor of a more technically-driven interpretation of agricultural development (Forclaz, 2019). While low and high modernism provide theoretical notions that guide this research there remains a historical reality that does not fit neatly into these concepts. In Indonesia, aspects of high modernism materialized under the regimes of Guided Democracy and New Order, although it remains to be examined in what ways previous concepts of rural

4) Sadjarwo, 'Pidato Pembukaan', in: Putusan konperensi Inspektur Kementerian Pertanian (Djakarta: n.p., 1951), 1-2, 1, ANRI, Arsip Sekretaris Negara Kabinet Perdana Menteri RI Tahun 1950-1959, jilid I, No. 2686. 
reconstruction informed more recent programs. ${ }^{5}$ This article offers but a start. It discusses the question why programs of rural reconstruction travelled to Indonesia and examines the various anti-colonial meanings that Indonesian politicians and planners attributed to rural reconstruction in the first decade of independence.

\section{Countering colonial claims of expertise}

Indonesia entered independence as a hungry nation. Before the war selfsufficiency in rice had been attained, yet conditions had since deteriorated. Former colonial extension officer Egbert de Vries (1949) summarized Indonesia's main agricultural challenges in an article published in Pacific Affairs. In the war and its aftermath, gardens, irrigation systems, rice fields, and roads had been destroyed, skilled laborers and experts had been killed, and large areas of Java suffered from soil erosion, deforestation and "unwise cutting of plantations." To make things worse, the Indonesian population continued to expand, causing an ever growing imbalance between consumption needs and production levels. The Indonesian nutritional scientist Poorwo Soedarmo estimated average daily consumption levels on Java to amount to "2050 gr. calories" and forty-three grams of protein. "This," he warned, "is the lowest rate in the entire world". 6

Food has received governmental attention from the beginning of the Revolution. As a matter of strategic, political and ideological concern, the Yogyakarta-based Republic of Indonesia government and the Dutch government in Jakarta installed various bodies to oversee and plan food procurement, distribution and production (Nawiyanto, 2013: 61-62). Hunger and malnutrition were powerful issues used to show the inadequacies in the opponent's efforts to take care of the people, hence challenge the other's claim to legitimacy. After all, as Tuong Vu (2003: 258-259) notes, in both pro-Dutch and pro-Republic discourses, helping the rakyat was construed as a moral obligation. The Republic of Indonesia issued a threeyear agricultural development scheme-the Kasimo Plan-in October 1947. Due to an economic blockade by the Dutch government and more so as a consequence of its first major military offensive, a food crisis in Republican territory loomed large (Adisubrata, 1980: 58). The Kasimo Plan stipulated a way out. The Dutch government in Jakarta, too, made plans to increase production. At the inauguration of the Provisional Federal Government for Indonesia in March 1948, Governor-General Van Mook called for "the

5) Pierre van der Eng (1996: 100-108) discusses this question in his seminal work on agricultural growth in Indonesia.

6) Poerwo Soedarmo, 'Tjeram [...] thd. Konferensi Para Inspektur Kementerian Pertanian,' Putusan Konperensi Inspektur Kementerian Pertanian (Djakarta: n.p., 1951), 1-6, 1, ANRI, Arsip Sekretaris Negara Kabinet Perdana Menteri RI Tahun 1950-1959, jilid I, No. 2686. 
systematic reconstruction of the entirety of Indonesia in every conceivable way" (Trouw, 10 March 1948: 1). The head of the postwar Department of Agriculture and Fishery, Wisaksono Wirjodihardjo, declared a "battle for agricultural production" in January 1949 and a welfare plan, the Wisaksono Plan, was presented in June 1949 (Het Dagblad, 28 January 1949: 2).

The enactment of food politics took place on national and international stages and involved claims of expertise. De Vries' contribution to Pacific Affairs, a scholarly quarterly published by the Institute of Pacific Relations in New York, illustrates this point for the pro-Dutch side. De Vries (1949: 130) praised prewar conditions. Colonial Indonesia offered "a striking example of harmonious interaction among a fertile soil, a tropical climate, an industrious population, and imported science, management and capital”. The future of both estate and peasant agriculture would likewise depend on foreign technical cooperation. The most critical factor, he stated, was "psychological," namely the "attitude of the Indonesian nation and government toward foreign investments and toward the presence ... of foreign entrepreneurs, managers and technical personnel," and crucially, "the ideological and political evolution of Southeast Asia as a whole" (143). By praising colonial times and identifying Indonesia as a nation in need of expert guidance, De Vries implicitly suggested that the archipelago's postcolonial development would be safest in Dutch hands. Not coincidentally, at the time of this article's publication, De Vries was coordinating the institutionalization of Dutch governmental technical assistance to "low-developed countries" (Van Soest, 1975: 227-229; Frey, 2011). State Secretary Wisaksono agreed that Indonesia required foreign assistance. "It is to be regretted," he argued in a speech broadcasted by Radio Indonesië, "that young academics hesitate to opt for a career in Indonesia. The Dutch have very much to offer. Their assistance will be invaluable in many different ways" (De Nieuwsgier, 14 October 1948: 4; Amigoe di Curacao, 29 November 1948: 1).

While the proponents of a postwar Dutch-Indonesian Union asserted the need for foreign assistance, the Republic opted for a different approach. In April 1946, Prime Minister Sjahrir offered India five hundred thousand tons of rice, showing to the world that food conditions in Indonesia were not as bad as Dutch propagandists claimed (Amrith, 2008: 1029; Vu, 2003: 250-252). The Kasimo Plan of October 1947 intended to realize principles and concepts in Pancasila and the Political Manifesto of November 1945. If cultivated properly, the rich soils of Indonesia would not only improve people's standards of living, but also contribute to global "peace, welfare, and order".

7) The author is working on locating the original text. This account of the Kasimo Plan is based on D. Groeneveld, '4 okt 1949 memo voor Secretaris Generaal voor Economische Zaken, van sectie Economische Planning, over Plan Kasimo', Leiden University Library, 
Kasimo's scheme did not mention the need for foreign cooperation. Instead, it promoted village development and agricultural education, notably by establishing BPMD in every kecamatan (sub-district). Where De Vries (1949) lamented the "conservativeness of the peasant and his unwillingness or inability to employ new techniques," the Kasimo Plan praised peasants' diligence and readiness to help one another (p. 131). The people had to be "activated," yet this was framed as a matter of increasing their confidence and thus as an act of overcoming a subjective legacy of colonial subjugation, not one of confronting traditionalism. Several months prior to the Plan's launch, Indonesia's largest peasant organization, the BTI, expressed similar views (Anonymous, 1947). Indonesian agriculture could be modernized by mobilizing knowledge that was readily available (pengetahoean jang ada). Indonesian agricultural experts and people's organizations had to work together, the one providing the brains (otak), the other the spirit (semangat).

In August 1949, representatives of the soon-to-be States of Indonesia, including a Republican delegation, gathered at the general agricultural experimental station in Bogor to discuss the future of Indonesian agriculture. ${ }^{8}$ The conference resulted in a blueprint of Indonesia's first postcolonial developmental scheme, which combined elements from the Kasimo and Wisaksono Plans. It presented a list of interventions to improve Indonesian agriculture, fishery, and livestock breeding. In his opening address, Wisaksono (1949: 580-581) emphasized the need for specialization, rationalization, and mechanization, and expressed his preference for "large companies, where animal power and labor-reducing technologies are efficiently used in order to employ less people". Wisaksono had travelled to the Netherlands in the previous year, where he was most likely impressed by Minister of Agriculture Sicco Mansholt's political endeavors to increase agricultural output. Wisaksono deemed the implementation of new scientific findings and the employment of foreign experts as indispensable. Apart from crossbreeding high-yielding varieties, the schedule called for research into fish cultures and the breeding of "genetically good animals." Pests would be combatted with "modern insecticides." It also contained elements more akin to Kasimo's proposals, including the establishment of seed farms to distribute new varieties, the advocacy of phosphate-based fertilizer, and a campaign to combat rat plagues. The Department of Agriculture and Fisheries would appoint an "acknowledged zoologist-rat expert" to improve traditional methods of eradication.

On paper, the RKI contained elements from both schemes, yet the postcolonial Ministry of Agriculture was selective in its implementation. As Sadjarwo explained in 1951, the ministry prioritized its "simple parts," that

Leiden, Special Collections, Collectie V.E. Korn, No. 17.

8) The conference and its outcome were discussed in Landbouw 21:12 (1949). 
is, those mainly derived from the Kasimo Plan and concerned with popular education and massive agricultural extension. ${ }^{9}$ The Wisaksono Plan, on the other hand, was generally held to focus on technical issues (Hadiwinoto, 1955: 2). The funding implications can be gleaned from the plan's budget for 1950. While the Republican Ministry of Agriculture reserved only 1.6 million gilders for the Wisaksono Plan, over 19 million guilders was allocated to the Kasimo Plan and related educational programs. ${ }^{10}$

To some degree, the ministry's decision to prioritize the Kasimo Plan had been pragmatic. Considering the grave state of Indonesian agriculture, and that of the state apparatus itself, it made sense to execute the RKI's "simple parts." At the same time, its emphasis on community development and education was based on nationalist ideological and reflected a broader governmental campaign of "mass education." These programs, Agus Suwignyo (2017) argues, served to teach the people what it meant to be citizens of the newly independent state of Indonesia. Being Indonesian entailed social obligations, values, and qualities that differed radically from those of colonial subjects. Postcolonial society required its citizens "to be self-reliant, self-motivated and bursting with energy for progress and achievements" (Suwignyo, 2017: 160). The future of Indonesia would depend on a psychological change, though not in the way that De Vries imagined. The new state would push the people to develop auto-activity.

\section{Auto-activity}

Instead of relying on foreign expertise and tools, the Ministry of Agriculture and its extension service made arrangements to deploy existing techniques, provide credit, encourage auto-activity and the establishment of cooperatives, and set up an infrastructure for mass education. This program of rural reconstruction was connected to developments in the 1920s and 1930s through the colonial careers of several prominent Indonesian politicians and officials. During the Revolution, the Republican Ministry of Prosperity staffed a small group of specialists who assumed key positions as senior governmental officials or university professors in the 1950s. ${ }^{11}$ Judged by their educational background, the group can be divided in two. Graduates from the Agricultural College in Wageningen (Hooge Landbouwschool) comprised the first group. This group included the following engineering (insinyur -

9) Sadjarwo, 'Pidato Pembukaan', 1. Also see Gunung Iskandar, "Pidato," Putusan Konperensi Inspektur Kementerian Pertanian (Djakarta: n.p., 1951), 5-9, p. 9, ANRI, Arsip Sekretaris Negara Kabinet Perdana Menteri RI Tahun 1950-1959, jilid I, No. 2686.

10) 'Pendjelasan Uang tentang Anggaran Belandja Rantjangan Istimewa Usaha Memperbesar Produksi untuk Tahun 1950', p. 3. ANRI, Arsip Kabinet Perdana Menteri RI Jogjakarta 1949-1950, No. 242.

11) For historical overviews of the Ministry of Agriculture, see Anon. (2005), Warsito (2002) and Warsito (2003). 
ir) graduates ir. Teko Sumodihardjo, ir. Anando, ir. Kaslan A. Tohir, ir. Saksono Prawirohardjo, ir. Gunung Iskandar, ir. Iso Reksohadiprodjo, and ir. Koesnoto Setyodiwiryo. The second group consisted of individuals who had been trained at agricultural schools in the Netherlands Indies, such as the Agricultural High School in Bogor (Middelbare Landbouwschool) or the Cultivation School in Sukabumi (cultuurschool). Notable figures in this second group were Soewardjo and Ignatius Kasimo. The agricultural development plan of the Republic carried Kasimo's name, because Kasimo, as Indonesia's Vice Minister of Prosperity, had written the introduction to the Plan. Its outlook on agricultural development however, reflects deliberations among governmental experts. All of them started their professional careers as consultants in the colonial agricultural extension service. To understand the decolonizing process, indeed anti-colonial concepts behind the Kasimo Plan, we need to go back to the late colonial era.

In the two decades prior to the war, some extension workers imagined their educational tasks as preparatory steps towards a decolonized Indonesia. The concept of "auto-activity" and semantic equivalences like self-help or self-activity (zelfwerkzaamheid) informed these actions. While these semantic equivalences have a long, transnational history (Büschel, 2014), the particular notion of "auto-activity" came from a fundamental critique of colonial economic policies articulated by the well-respected economist Julius H. Boeke. Dutch colonial culture, after all, was not monosemic, but contained different voices and political orientations. While readers on various sides of the political spectrum made use of Boeke's ideas, "auto-activity" could take on an exclusively anti-colonial meaning.

"Auto-activity" first appeared in a lecture entitled 'Auto-activity and Autonomy,' presented by Boeke to the Indies Society in The Hague in 1922 (Nieuwe Rotterdamsche Courant, 12 October 1922: 2; Boeke, 1923). Previous attempts to develop the Indies had failed because the state had implemented its policies without direct involvement of the indigenous population. By directing its attention towards objects (de zaak) like irrigation, husbandry, and education rather than towards the users, the state had taught the people (bevolking) to accept results without considering how these results came about, [and] to wait for the help of others instead of making an effort themselves." The state had thereby diminished the people's capability to organize themselves, "turning them into a multitude of weak, solitary individuals." Boeke introduced the term "auto-activity" to identify a new and experimental field of governmental intervention, directed towards the development of indigenous forces. Invoking the colonial trope of the childlike native (landskinderen), he states that Maria Montessori's education methods had to be applied to colonial society. Nurturing feelings of responsibility and economic self-interest would have to precede the granting of economic autonomy. 
Boeke therefore recommended promoting indigenous organizations with common interests and to leave as much as possible to the landskinderen themselves. Policy had to shift "from the objects to the subjects."

While members of the Indies Society disagreed with Boeke on multiple levels, its chairman and Boeke's previous thesis supervisor Cornelis van Vollenhoven concluded the session by expressing the hope that the lecture would be read by many "Westerners and Indonesians" (Nieuwe Rotterdamsche Courant, 12 October 1922). And so it happened. Throughout the 1920s and 1930s, various organizations and activists adopted the notion of autoactivity to argue that top-down colonial governance had disempowered the indigenous population. The chairman of Boedi Oetomo, Koesoemo Soetojo for example, described his organization's goals as "to economically mobilize the masses, to push them towards auto-activity in order to find solace (heil) in self-help" (De Sumatra Post, 12 March 1927: 5). In more radical branches of Indonesian nationalism, including the Taman Siswa educational movement, Perhimpoenan Indonesia, and Sukarno's Partai Nasional Indonesia (Indonesian National Party), notions of auto-activity likewise circulated (Elson, 2008: 59; McVey, 1967; Ingleson, 1975). ${ }^{12}$ In 1923, Iwa Kusumasumantri, chairman of the executive committee of the Perhimpoenan Indonesia, stated that every Indonesian had to strive for a form of government responsible to the people in the true sense of the word, "to the best of his ability, through his own talents and powers and independently of foreign "help" (Kusumasumantri, cited in Ingleson, 1975: 5). In the eyes of Mohammad Hatta, colonial power partially rested on a psychological factor, namely the "injection of the idea of the superiority of the white race in Indonesian consciousness and the suggestion of national impotence" (Hatta, cited in Pols, 2018: 129). As a consequence, Indonesians doubted their own abilities. To rectify the damaging psychological effects of colonialism, Hatta and members of the Perhimpoenan Indonesia proposed a policy of non-cooperation. As Hans Pols

12) Founded by Ki Hadjar Dewantara in Yogyakarta in July 1922, the Taman Siswa ("Garden of Students") was an anti-colonial educational movement that quickly spread across Java, Sumatra and Kalimantan. It strove to strengthen the pupils' sense of cultural belonging and was based on seven principles, including freedom of individual development, the nurturing of self-esteem, and embedment of education in local culture.

Perhimpoenan Indonesia (Indonesian Association) was the association of Indonesian students in the Netherlands. Founded in 1908 as Indische Vereeniging, its name was changed to Indonesische Vereeniging (1922) and Perhimpoenan Indonesia (1925). These transformations reflected increased political activism. Its politics was based on anti-capitalism, anticolonialism, nationalism, and non-cooperation. Prominent members included Mohammad Hatta, Soetomo, Ali Sastroamidjojo, and Soetan Sjahrir.

Partai Nasional Indonesia (Indonesian National Party) was established by Soekarno in Bandung in 1927. Its goal was a politically and economically independent nation-state that comprised the entire Indonesian archipelago. Like Perhimpoenan Indonesia, it emphasized non-cooperation and mass action. In 1931 the PNI was dissolved after prominent leaders, including Soekarno, had been imprisoned by the colonial state. 
(2018) has summarized, non-cooperation would "promote self-confidence, self-help and auto-activity, and result in improvements in the everyday life of Indonesians" (p. 130). From 1925 onwards, Perhimpoenan Indonesia included "building a nationalism based on conscious, self-reliant mass action" amongst its statement of principles (Ingleson, 1975: 11). In Indonesië klaagt aan! (Indonesia Accuses!), Soekarno (1931) emphasized mass action and selfhelp. Soekarno approvingly quoted a member of De Stuw, stating that the Indonesian people had become increasingly dependent on "the foreign element, which moves us ever further away from the goal: The Indies for Indies people" (p. 47). "Important improvements," he maintained, "can only be achieved by our own work, our own abilities, by our power" (p. 108).

Linkages between nationalist interpretations of auto-activity and postwar visions of agricultural development can be illustrated by a 1941 publication on popular education by Teko Sumodiwirjo. In the final years of the Revolution, Teko was in charge of the Ministry of Prosperity's sections for commerce, cooperatives, collection, storage and distribution (Anon., 2005: 35). After the war, he became one of the first three Indonesian professors at University of Indonesia's (Universitas Indonesia - UI) Faculty of Agriculture in Bogor, where he served as the chair for Rural Sociology. In the 1950s he published several booklets on cooperatives and adult education. "Some educators," Teko Sumodiwirjo (Soemodiwirjo, 1941) ${ }^{13}$ wrote, "stick to the idea, that the population (bevolking) will never ever be able to take care of its own business." "Because of this," he continued, "they themselves do all the work and make all the decisions, without involving the people. The population is nothing but a work force" (p. 453). Citing prominent progressive officials like H.J. van Mook and Charles van der Plas, and referring to Boeke's critique of colonial developmental policy, Sumodiwirjo argued that the colonial state had transformed Indonesians into passive objects, producing "a weak and feeble whole" (p. 455-456). "The population," he asserted, "wants activity (werkzaamheid) according to its own initiative, according to its own taste and ... according to its own speed. Every painting comes with its own unique frame" (p. 454). To introduce the "principle of auto-activity" would undoubtedly cause troubles, yet the biggest challenge would be to practice self-restraint. "It is the farmer," he emphasized, "who has to bring about improvement".

But the question to be answered was how to stimulate auto-activity among Indonesian peasants and workers? Boeke had indicated that the best way to shift government policy from the object to the subject should be determined experimentally. In Sumodiwirjo's view, a proven model could

13) After the war, Teko Sumodiwirjo used the new spelling of Bahasa Indonesia to write his name. For consistency sake, I use the modern spelling of Sumodiwirjo's name both before and after the war. 
be taken from the work of John Lee Hydrick, an American physician, who on behalf of the Rockefeller Foundation, directed a rural hygiene project in Java between 1924 and 1939. Hans Pols (2018) has shown that Hydrick's endeavors pushed Indonesian physicians-notably the STOVIA-graduate and member of the Volksraad Abdul Rasjid-to articulate a medical nationalism emphasizing the need for health care benefiting the indigenous population (p. 138-160; Anderson \& Pols, 2013). Yet the presence of Hydrick in the Netherlands Indies was important for other reasons, too. With regard to American Presbyterian missionaries at the Allahabad Agricultural Institute, India, in the era of late colonialism, Prakash Kumar (2020) has argued that the American approach to rural education in the colonial context had features which made it distinctive from the British colonial state. Inspired by an early campaign against hookworm in the southern United States, these missionaries emphasized learning by doing, self-help and self-reliance, and a small-scale approach. Indeed, Abdul Rasjid targeted the Dutch colonial state for its "inability, as a foreign power, to win the full cooperation of ordinary Indonesians" (Rasjid, cited in Abeyasekere, 1986: 9). If the government took its self-assigned task to improve living conditions of poor peasants seriously, it would need to initiate a people's initiative in health care. References in Teko's article (1941) to Hydrick's writings indicate that Teko, too, took this to be a key element in envisioning a rural education in pursuit of national independence.

Hydrick (1937) wrote that the spirit of his approach was that the people "should be lead, not driven. They should be stimulated and lead to express a desire to live more hygienically. It is the task of the health worker to create this desire" (p. 3). Hydrick identified co-operation and active involvement of the people as the only possible ways to cause permanent change in people's behavior. Sumodiwirjo adopted many of Hydrick's recommendations as to how to involve villagers and teach them to do things themselves. While the extension specialist's expertise in technical matters had to be impeccable, he emphasized that effective extension dependent on the consultant's ability to socialize with the rural population and establish rapport and trust. Extension workers had to visit pay house visits, be humble and informal, have conversation about koetjes en kalfjes (small talk), oppose the urge to reprimand in case villagers made a mistake, be as funny as possible, and communicate in a clear and non-technical language. Extension officers had to know the "psyche" or "mentality" of the tani (farmer), to speak their language, and to be familiar with the harsh realities of their daily lives. While many extension officers complained about the conservatism of peasants, Teko stated that officers often did not express their ideas clear enough nor did they take into account local circumstances and practices of the population. And even if peasants were cautious in introducing new methods or crops, this was often 
for good reasons. The gut feeling and lifelong experience of peasants acted as a salutary check to counter "pet projects of bureaucrats" (Soemodiwirjo, 1941: 458). "Knowledge, understanding, respect, and love," the extension specialist concluded, are indispensable values in extension work (p. 459).

A paternalistic mindset is evident in Sumodiwirjo's writings. "In many ways," he asserted, "the person to be educated is still a child” (p. 442). To win their hearts, peasants had to be approached as such. Sumodiwirjo recommended the use of games, contests, excursions, rewards, and exhibitions. Visual demonstration was deemed essential. To convince peasants to adopt a new type of crop or cultivation method, they had to see the facts and results. Visits to demonstration sites had to be attractive, even fun, by handing out refreshments or snacks. ${ }^{14}$ The extension specialist also supported ketoprak, traditional theatre in Java, which provided at times hilarious blends of slapstick comedy, singing, and Javanese story-telling. In East Java, Teko had successfully combined ketoprak with agricultural education. Sumodiwirjo described the combination of ketoprak and extension as a successful strategy to break-down perceived hierarchies between government officials and the local population.

Teko identified the persona of missionary as the ideal model for the extension specialist combining all the required character traits to help others help themselves. The comparison had been around for a while. In 1928 Egbert de Vries for example, had likened agricultural extension to the modern methods of missionaries (Het Nieuws van den Dag, 18 February 1928: 1). In both cases, building trust was seen as the single most important issue. Instead of propagating ideas top-down, one had to proceed from the bottom up. In fact, Sumodiwirjo's methodological considerations did not solely come from foreign experts like Hydrick, but also reflected Dutch colonial extension methods. Still, Teko Sumodiwirjo and De Vries differed on the proper scale of extension work. De Vries represented the point of view, officially adopted by the colonial extension service in the late 1920s, extension efforts should be concentrated on outstanding farmers, who could set "pioneering examples" to others (Van der Eng, 1991: 41). ${ }^{15}$ This individualist approach clashed with the nationalist call for mass action. Teko Sumodiwirjo, like Mohammad Hatta, favored the establishment of cooperatives in which both richer and poorer people would join forces. In the late 1930s, Teko, together with Margono Djojohadikoesoemo, headed the Cooperative Service of the colonial Departement of Economic Affairs. Teko's ideal, De Vries recollected in the late 1980s, "was to combine the cooperative

14) This, too, seems to have been inspired by Hydrick's rural hygiene projects. See Steiner (2006).

15) , 41. This policy was described by the sociologist Wim Wertheim as "betting on the stronger." See Moon, Technology and Ethical Idealism, 110. 
movement and the extension service in community institutes, which would be maintained by the people themselves" (Van der Eng, 1991: 41-42; Lutfhi, 2011: 162). Others, too, endeavored to further promote cooperation and self-help among Indonesian peasants. In 1941, Soewardjo, who would direct Indonesia's People's Agriculture Service until 1958 and together with Teko played a key role in the creation of the BPMD, even received a colonial medal in acknowledgement of his efforts to improve the living conditions of the little man' through private courses and founding tani kringen (farmer circles) (Soerabaijasch Handelsblad, 17 December 1941: 12).

In short, the concept of auto-activity could be mobilized to mount criticism against the colonial-era agricultural policy, and thus a particular style of governance. Because colonial extension policy did not ascribed to peasants a role in their own development, it engendered a perpetual relationships of dependency. Apart from inhibiting potential individual and community development, it obstructed, more fundamentally, the rise of an independent Indonesian nation state. After the war, the choice between the Kasimo Plan or the Wisaksono Plan involved more than purely techno-agricultural matters but a philosophical and political question of how to nurture an independent nation.

\section{New People}

After the war, the People's Agriculture Service assumed many responsibilies. It operated over two hundred seed farms that distributed seed that had been selected by the General Agricultural Research Station in Bogor; it ran close to eighty demonstration farms to encourage dry-land farming; it conducted experiments and tests in the application of fertilizers and pesticides, and the cultivation of fruit and vegetables; and it published brochures, journals and magazines, including the monthly journal Pertanian and the farmers' magazine Tani Mukti and Pak Tani. In the immediate postwar years, the rehabilitation of the irrigation systems also ranked high on the extension service's priority list, as it was an essential part of the RKI. In 1953, $13000 \mathrm{~km}$ of irrigation channels and 3700 dams had been restored, with over one million hectares of wetland agriculture benefiting from improved irrigation. Apart from its material consequences, the service praised the uplifting psychological effect that construction work had on the rural population. Still, the extension service prioritized its educational programs. In a brochure on agricultural education, Soewardjo (Suwardjo, 1954: 4) wrote that "it is not the improvement of technology that is most important, the center of gravity is the human factor". ${ }^{16}$ The development of new technologies was only useful if peasants understood the technology and applied them voluntarily. Yet on a more fundamental

16) After the war, Soewardjo most of the time used the old spelling of Bahasa Indonesia to write his name. For consistency sake, I will use the old spelling too. 
level, education was not about the application of technology. Agricultural education, Soewardjo explained in 1956, concerned "awareness education" (pendidikan kesadaran). ${ }^{17}$ Peasants needed to realize that the interests of society and state overlapped, and that the materialization of a prosperous future lay in their own hands. Development practices also often intersected with the production of, in Soewardjo's words, "new people" (orang baru) (Diouf, 1997; Kalinovsky, 2018: 144-174; Pols, Thompson \& Warner, 2017). The officers of the extension service aimed at nothing less than the construction of a nation and its citizen.

Throughout the 1950s the number of students involved in agricultural training programs increased rapidly. These programs were intended to provide education on a large scale (pendidikan massaal). This kind of education, Soewardjo (Suwardjo, 1954: 4) stated, had to be organized as cheaply, and for as many, as possible, in accordance with local circumstances and the level of people's knowledge. The length of these programs varied from six months to two years. The programs could be formal or informal. The most successful program was the Village Peasant Course (Kursus Tani Desa, hereafter: KTD), which increased from 246 courses in 1950 to 2656 in 1955, provided for more than seventy thousand students (Hadiwinoto, 1955: 5). ${ }^{18}$ This oneyear program was geared towards older peasants-both male and female, although they were instructed separately-and served to improve desa (village) agriculture. Twice a week, students received education from a mantri tani (farming supervisor) who provided practical instructions on how to improve local cultivation techniques. According to R. Kiswarin, chief of the Ministry of Agriculture's section for education, the KTD had many benefits. ${ }^{19}$ Apart from increasing the number of "peasant contacts" (kontak tani) who could act as intermediaries between the extension service and peasants' larger communities, these programs "change the soul of the peasant people (jiwa rakjat tani) from static to dynamic, nurture the people's auto-activity, and strengthen the spirit of gotong rojong (mutual help) and unity."

To reach Indonesia's youth, the extension service set up Rural Youth Courses (Kursus Pemuda Tani, KPT). The program was considerably smaller and was mainly run in West Java. Like the KTD, the youth program served to increase the practical know-how of adolescents, yet crucially it also intended to accommodate the unemployed and make them "tani-minded" (Suwardjo,

17) Soewardjo, 'Kata pengantar', Notulen Konperensi Inspektur Djwatan Pertanian Rakjat tg. 26 s/d 21 Maret 1956 di Malang (Jakarta: Pusat Djawatan Pertanian Rakjat, 1956), p. 143, Bogor, Pusat Perpustakaan dan Penyebaran Teknologi Pertanian, Special Collections.

18) Kiswarin, 'Pendidikan Pertanian', Notulen Konperensi Inspektur Djwatan Pertanian Rakjat tg. 26 s/d 21 Maret 1956 di Malang (Jakarta: Pusat Djawatan Pertanian Rakjat, 1956), 148-170, p. 163, Bogor, Pusat Perpustakaan dan Penyebaran Teknologi Pertanian, Special Collections.

19) Kiswarin, 'Pendidikan Pertanian', 151. 
1954: 7). The educated needed to develop a love for nature, agriculture, and the nation. Indonesia's youth would be turned into "new people," Soewardjo stated, with "new views" on the problems of society and the nation. ${ }^{20}$ Teaching children to love agriculture could diminish the steady stream of adolescents moving to the cities to seek their fortune. The noble tasks of rural workers was by no means inferior to those of government officials and other occupations, or so the pemuda were instructed. Children could enroll in a KPT after they finished elementary school at the age of twelve to fourteen. In elementary schools in West Java, pupils also received education to foster feelings of love for agriculture and nature. "Never present cities as the only places to increase knowledge and find valuable work," Soewardjo (Suwardjo, 1954: 5) wrote. "On the contrary," he continued, "the desa should be presented as a very important part of the nation, as one of its Pillars ("Soko guru" Negara), and as a source of natural beauty, so that the desa becomes more attractive than the city." Adolescents should appreciate the village's beauty and the importance of agriculture to national welfare.

Young adult literature could be mobilized to foster feelings of love for agriculture and nature. One example is Why Amat wants to go to agricultural school, a short story written bye Pak Dulah in 1950. The book tells the story of a young boy named Amat, who learns to respect everything that is alive and is beneficial to mankind. On this account caterpillars should be killed, lest they eat all father's vegetables. In the story Amat tells his father that he wants to become a farmer too, "just as smart as you," his father replies that Amat should go to agricultural school. "We learned how to be farmers from our fathers, but there is a lot that we can't teach you" (Dulah, 1950: 21). Much valuable knowledge, he continued, is recorded in books and magazines, yet you have to study first in order to understand these. The story concludes with Amat dreaming of agricultural school. He planted "rice as big as pigeon eggs, cultivated fishes that were one meter long, and cultivated cassava as big as coconut trees".

In comparison to colonial times, agricultural courses did not introduce fundamentally new elements to the extension officer's repertoire. The colonial extension service, after all, had offered rural education. After the war, the People's Agriculture Service drastically expanded the program and crucially, inserted a new nationalist foundation. The Balai Pendidikan Masjarakat Desa, on the other hand, did present a new development. The BPMD were part of the Kasimo Plan and received their name at a conference of the Extension Service held in Madiun in July 1948. Both Teko Sumodiwirjo and Soewardjo had been involved in its creation. The service aimed at establishing one BPMD in each and every kecamatan (sub-district), yet for various reasons progress was slow. In 1955, 315 out of 1400 proposed centers had been completed

20) Soewardjo, 'Kata pengantar', 143. 
(Hadinoto, 1955: 5). Most of these were located on Java. Every center was planned to have a meeting place and office, a library, a samples room (to take for example soil samples), and a storage area for seeds, pesticides, and tools. Soewardjo (1953) emphasized that the centers should have the appearance of ordinary gardens "and need to be shaped in such a way, that peasants don't feel afraid to enter and discuss what is on their minds" (p. 4). The aim was to increase the farmers level of knowledge utilizing movie screenings, demonstrations, gatherings, and a library. (Kiswarin, 1956: 84). The BPMD, administrated by the extension service, were also made available for use by other governmental agencies.

The BPMD were intended as places for society and government to meet, free from fear and to strengthen a sense of kinship (Suwardjo, 1954: 11). Ideally, information would flow in two directions. BPMD leaders assumed responsibility for the implementation of governmental development programs. Villagers, on the other hand, could use the centers to communicate their wishes and concerns to the government. While the BPMD operated within the context of national politics, Soewardjo (1953) maintained that politics should be avoided. "Because the village community comprises several groups, such as farmers, traders, workers, government officials, and artists, the BPMD should be neutral and is not allowed to be used for political negotiations" (p. 4). The qualities that needed to be presented by BPMD leaders corresponded to the ones described by Teko Sumodiwirjo before the war, namely kindness, patience, and a willingness to help others, like a brother to a brother. "The village community," Soewardjo (1953) warned in a brochure on the BPMD, "does not want to be an object, but rather wants to be a living subject that develops auto-activity” (p. 8). This particular booklet contains an English translation by Fayette M. Parvin, an agricultural extension specialist dispatched to Indonesia by the US Technical Cooperation Agency. Parvin added to Soewardjo's usage of "auto-activity" the concept of "selfhelp" to translate this notion embedded in the Dutch colonial context to an international audience. Ultimately, the BPMD would foster what Soewardjo described as "New Desa" or "Desa Pancasila" (p. 15). Not new in a material sense, but in the sense of a spiritual renewal. Revitalized by the nationalist spirit of unity and gotong royong, villagers would raise themselves out of poverty by undertaking auto-activity. Villagers would set up organizations to solve socio-economic problems to benefit the entire community. A noncommercial bank provided credit and manage governmental subsidies, with the additional intent of keeping villagers out of the hands of usurers. Seed and food would be kept in communal granaries. The BPMD, in short, would help peasants to help themselves and contribute their talents and skills to the making of a new society.

Apart from its educational programs and the BPMD, the extension 
service deployed various additional strategies to awaken peasants' autoactivity, including exhibitions, film screenings, and excursions. In order to encourage auto-activity, the extension service also organized contests not only between individuals, but also between villages and kecamatan. In the wet season of 1950-1951, the service set up a competition between all kecamatan in Java and Madura (Soewardjo, 1955). The competition had two goals: to speed up the rehabilitation process of the tertiary irrigation system and to increase rice production. All participating kecamatan received a financial reward, which varied from Rp. 1000 to Rp. 10 000. Other gifts included cows, goats, agricultural tools, and seeds for rice, fruits and vegetables. Local working committees advised villagers on how to increase production yields. The application of green fertilizers, compost and goat manure received a boost, as did the cultivation of the rice variety Bengawan in Central and East Java. A competition likewise stimulated gotong royong, cooperation amongst villagers themselves and between villagers and the government. The government could reduce its expenditure on the rehabilitation of irrigation systems by 80 percent. Despite the fact that the rice season of 1950-1951 suffered from adverse weather conditions, final harvest results surpassed the predictions of scientific experts in Bogor, a result which Soewardjo (1955) in large part attributed to "the peasants' auto-activity ... which runs (mendjalankan) its actions" (p. 110). Contests were not a goal, but a means to approach the people.

\section{Conclusion}

In a 1955 lecture on 'Co-operatives as Education for Auto-activity,' Vice President and Bapak Koperasi (the Father of Cooperatives) Mohammad Hatta (1957) raised objections to the burgeoning industry of technical assistance. "When means are sought to help (...) backward countries, an inordinate amount of weight is placed on economic rationalism," he stated, "The emphasis is on capital aid and technical skill” (pp. 29 \& 31). Planners should rather focus on psychological factors to awaken "the productive energy of the population that has hitherto lived under the pressure of an inferiority complex." A higher standard of living could be obtained by utilizing "persons of medium capabilities." These words by one of Indonesia's most prominent economists give a good illustration of the argument that I seek to develop in this article. The rural reconstruction program, set out in the Kasimo Plan and seen its postwar implementation, contained an implicit reversal of a colonial hierarchy of knowledge. To produce food for the people, the Republic of Indonesia did not need foreign assistance and modern knowledge from the West. The alleged lack of science and technology, in other words, could not be used as an argument to justify the continuation of colonial practices and hierarchies in the archipelago. Instead, a masyarakat adil dan makmur (a just 
and prosperous community) was to be established by mobilizing the masses. What prevented pak dan mbak tani (farmers both male and female) from dedicating their lives to the new nation, was not their levels of skill or knowhow. On the contrary, in the politics of knowledge and decolonization, it is in fact the validation of local knowledge that sustains arguments against colonial rule. The Indonesian masses were held back by feelings of inferiority and self-doubt injected, in the words of Hatta, by the Dutch. Indonesian leaders envisioned programs of rural reconstruction, auto-activity, and cooperation as means to overcome this situation. These programs therefore embodied a vision of what the postcolonial nationstate was to be namely, a radical reversal of the colonial state, one that empowered the people, valued their skills, and fostered their talents.

Still, programs of mass education and the discourse of auto-activity could have new, deeply colonizing consequences. In prewar nationalist discourses, the notion of auto-activity provided ammunition against colonial power and paternalistic policies. Like the notion of development, auto-activity could be used as "a claim-making construct" to discredit the colonial state (Cooper, 2010: 12). If the people's auto-activity was to be pushed, who else than those belonging to the people themselves would be the most suitable candidate to guide the process? After the war, auto-activity became engrained in the politics of postcolonial nation-building. This is encapsulated in a peculiar statement, made at the time by politicians and administrators, that the tani had be made "tani-minded." Peasants, in other words, had to be transformed into a particular kind of peasant who inhabited ideal villages (Unger, 2015: 71). Rural life remained a key site for state intervention. Peasants needed to grasp the fact that the interests of state and society coincided with their own. They would work hard and full of nationalist zeal within the parameters set by the state. The sphere of action within which peasants could enact their auto-activity was thus restricted. These peasants should not raise questions such as whether water was equally distributed in a local irrigation system nor should they occupy former colonial plantations "illegally." Auto-activity, in other words, could result in good and bad behavior, and therefore needed to be guided. Elements of top-down, authoritarian agricultural policy that emerged during the Guided Democracy and especially the first decade of the New Order can be found in these rural reconstruction programs, although the ideology of a quick, technological fix was largely absent.

Still, as early as 1951, Gunung Iskandar, the Secretary-General of the Ministry of Agriculture, noted that people tended to say various things about the peasants. ${ }^{21}$ Whereas he himself did not deny "good qualities" like

21) Gunung Iskandar, "Pidato," Putusan Konperensi Inspektur Kementerian Pertanian (Djakarta, 24 sampai 29 Djuli, 1951), 5-9, 9. ANRI, Arsip Sekretaris Negara Kabinet Perdana Menteri RI Tahun 1950-1959, Jilid I, No. 2686. 
politeness and diligence, he also commented upon their conservativeness (kolot) and backwardness. Programs of auto-activity would result in progress, but he stated, only to a very limited degree. To push beyond these limits, Indonesia required foreign assistance in the fields of research and science. By the time Hatta had stepped down as Vice President, Gunung Iskandar headed an early-Guided Democracy rice intensification program.

\section{Acknowledgements}

The author expresses appreciation to all participants at the Construction of Indonesian Knowledge Cultures since Independence Workshop held at UGM in February, 2020. A special mention goes to Farabi Fakih, who posed some challenging questions.

\section{References}

\section{Unpublished Archives}

Arsip Nasional Republik Indonesia, Jakarta, Indonesia

Kabinet Perdana Menteri RI Jogjakarta 1949-1950

Kabinet Presiden 1950-1959

Sekretaris Negara Kabinet Perdana Menteri RI Tahun 1950-1959, jilid I

Leiden University Library, Special Collections, Leiden, the Netherlands

Collectie V.E. Korn

Pusat Perpustakaan dan Penyebaran Teknologi Pertanian, Special Collections, Bogor, Indonesia

\section{Published primary and secondary sources}

Abeyasekere, Susan (1986). 'Health as a Nationalist Issue in Colonial Indonesia', in David P. Chandler and M.C. Ricklefs (eds.). Nineteenth and Twentieth Century Indonesia: Essays in Honour of Professor J.D. Legge. Australia: Centre of Southeast Studies Monash University, 1-14.

Adisubrata, Y. (ed.) (1980). I.J. Kasimo: Hidup dan Perjuangannya. Jakarta: Penerbit PT Gramedia.

Amrith, Sunil (2008). 'Food and Welfare in India, c. 1900-1950', Comparative Studies in Society and History 50, 4: 1010-1035.

Anderson, Warwick \& Hans Pols (2012). 'Scientific Patriotism: Medical Science and National Self-Fashioning in Southeast Asia', Comparative Studies in Society and History 54, 1: 93-113.

Anononymous (1947). Mentjapai Kemakmoeran dengan: I Modernisasi Pertanian. Jogjakarta: n.p.

Anonymous (2005). 100 Years of The Ministry of Agriculture in Republic of Indonesia. Jakarta: Ministry of Agriculture of the Republic of Indonesia in Cooperation with Visiprompt.

Boeke, J.H. (1923). 'Auto-activiteit naast Autonomie', Blaadje voor het Volkscredietwezen 11, 3: 53-85.

Büschel, Hubertus (2014). Hilfe zur Selbsthilfe: Deutsche Entwicklungsarbeit in Afrika 1960-1975. Frankfurt: Campus.

Cooper, Frederick (2010). 'W riting the History of Development', Journal of Modern 
European History 2010, 8: 5-23.

De Vries, Egbert (1949). 'Problems of Agriculture in Indonesia', Pacific Affairs 22, 2: 130-143.

Diouf, Mamadou (1997). 'Senegalese Development: From Mass Mobilization to Technocratic Elitism', in Frederick Cooper and Randall Packard (eds.), International Development and the Social Sciences: Essays on the History of Politics of Knowledge. Berkeley: University of California Press, 291-319.

Dulah (1950). Mengapa AMAT Hendak Kesekolah Pertanian. Djakarta: Pustaka Rakjat N.V., 1950.

Elson, R. E. (2008). The Idea of Indonesia: A History. Cambridge: Cambridge University Press.

Fischer-Tiné, Harald (2018). 'The YMCA and Low-Modernist Rural Development in South Asia, c. 1922-1957', Past and Present 240, 1: 194-234.

Forclaz, Amalia Ribi (2019). 'From Reconstruction to Development: The Early Years of the Food and Agriculture Organization (FAO) and the Conceptualization of Rural Welfare, 1945-1955', The International History Review 41, 2: 351-371.

Frey, Marc (2011). 'Dutch Elites and Decolonization', in Jost Dülffer \& Marc Frey (eds), Elites and Decolonization in the Twentieth Century. Houndsmill: Palgrave Macmillan, 56-73.

Gilbert, Jess (2003). 'Low Modernism and the Agrarian New Deal: A Different Kind of State', in Jane Adams (ed.), Fighting for the Farm: Rural America Transformed. Philadelphia: University of Pennsylvania Press, 129-146.

Hadiwinoto, Soebari (1955). 'Usaha dan langkah Djawatan Pertanian Rakjat selama Tahun 1945-1955', Pertanian 6, 7: 2-7.

Hatta, Mohammad (1957). 'Co-operatives as Education for Auto-activity', in Mohammad Hatta. The Co-operative Movement in Indonesia. Ithaca: Cornell University Press, 21-35.

Hydrick, J.L. (1937). Intensive Rural Hygiene Work and Public Health Education of the Public Health Service of Netherlands India. Batavia-Centrum: n.p.

Ingleson, John (1975). Perhimpunan Indonesia and the Indonesian Nationalist Movement 1923-1928. Monash University: Centre of Southeast Asia Studies.

Kalinovsky, Artemy M. (2018). Laboratory of Socialist Development: Cold War Politics and Decolonization in Soviet Tajikistan. Ithaca: Cornell University Press.

Kiswarin (1956). 'Usaha Mempertinggi Pengetahuan Petani', Almanak Tani 1956. Jakarta: Kementerian Pertanian, 77-88.

Kumar, Prakash (2020). “Modernization” and Agrarian Development in India, 191252', The Journal of Asian Studies 79, 3: 633-658.

Luthfi, Ahmad Nashih (2011). Melacak Sejarah Pemikiran Agraria: Sumbangan Pemikiran Mazhab Bogor. Yogyakarta: STPN Press.

McVey, Ruth (1967). 'Taman Siswa and the Indonesian National Awakening', Indonesia No. 4, Oct.: 128-149.

Moon, Suzanne (2007). Technology and Ethical Idealism: A History of Development in the Netherlands East Indies. Leiden: CNWS Publications.

Nawiyanto (2013). 'The Politics of Food and Food Security during Indonesia's Old Order (1945-1965)', Lembaran Sejarah 10, 1: 60-73.

Pernet, Corinne A. \& Amalia Ribi Forclaz (2019). 'Revisiting the Food and Agriculture Organization (FAO): International Histories of Agriculture, Nutrition, and Development', The International History Review 41, 2: 345-350. 
Pols, Hans, C. Michele Thompson \& John Harley Warner (eds) (2017). Translating the Body: Medical Education in Southeast Asia. Singapore: NUS Press.

Pols, Hans (2018). Nurturing Indonesia: Medicine and Decolonisation in the Dutch East Indies. Cambridge: Cambridge University Press.

Scott, James C. (1998). Seeing Like a State: How Certain Schemes to Improve the Human Condition have Failed. New Haven and London: Yale University Press.

Sinha, Subir (2008). 'Lineages of the Developmentalist State: Transnationality and Village India, 1900-1965', Comparative Studies in Society and History 50, 1: 5790.

Soekarno (1931). Indonesië Klaagt Aan! Pleitrede voor den Landraad te Bandoeng op 2 December 1930 gehouden door Ir. Soekarno. Amsterdam: De Arbeiderspers.

Soemodiwirjo, Teko (1941). 'Eenige Aanteekeningen uit de Practijk van de Voorlichting aan de Bevolking'. Landbouw 17, 7: 431-459.

Soewardjo (1953). BPMD: Balai Pendidikan Masjarakat Desa - Village Education Center. Jakarta: Pusat Djawatan Pertanian Rakjat.

Soewardjo (1955). 'Perlombaan Pertanian Sebagai Pendorong Kediatan Kaum Tani. (Kegiatan Bekerdja Sendiri)', Almanak Tani 1955. Djakarta: Kementerian Pertanian, 102-110.

Staples, Amy S. (2000). 'Norris E. Dodd and the Connections between Domestic and International Policy', Agricultural History 74, 2: 393-403.

Steiner, Eric A. (2006). 'Colonial Theatres of Proof: Representation and Laughter in 1930s Rockefeller Foundation Hygiene Cinema in Java', Health and History 8, 2: 14-44.

Sumodiwirjo, Teko (1953). Beberapa Soal sekitar Pak Tani dan Hubungannja dengan Gerakan Koperasi: Pidato Pelantikan diutjapkan pada Pelantikannja sebagai Guru Besar Luar Biasa dalam Mata Peladjaran Koperasi pada Fakultet Pertanian di Bogor pada tgl. 28 Maret 1953. N.p.

Suwardjo (1954). Pendidikan Pertanian. Jakarta: Pusat Djawatan Pertanian Rakjat.

Suwignyo, Agus (2017). 'Mass Education: Elite's Citizenship Project and the Making of Public Intellectuality in Early Independent Indonesia', Paramita 27, 2: 154167.

Unger, Corinna R. (2015). Entwicklungspfade in Indien: Eine internationale Geschichte 1947-1980. Göttingen: Wallstein Verlag.

Van der Eng, Pierre (1991). 'An Observer of 65 Years of Socio-Economic Change in Indonesia: Egbert de Vries', Bulletin of Indonesian Economic Studies 27, 1: 39-55.

Van der Eng, Pierre (1996). Agricultural Growth in Indonesia: Productivity and Policy Impact since 1880. Houndmills: Macmillan Press.

Van Soest, Jaap (1975). Het Begin van de Ontwikkelingshulp in de Verenigde Naties en in Nederland 1945-1952. Tilburg: Zwijsen.

$\mathrm{Vu}$, Tuong (2003). 'Of Rice and Revolution: The Politics of Provisioning and StateSociety Relations on Java, 1945-1949', South East Asia Research 11, 3: 237-267.

Warsito (2002). Mengelang Satu Abad Departemen Pertanian. Bagain 1, 1905 s/d 1945. Jakarta: Departemen Pertanian.

Warsito (2003). Organisasi Departemen Pertanian 1945-1960. Jakarta: Departemen Pertanian.

Wirjodihardjo, M. Wisaksono (1949). 'Openingsrede van de Staatssecretaris voor Landbouw en Visserij', Landbouw 21, 12: 577-583. 


\section{Magazines and Newspapers}

Amigoe di Curacao, 29 November 1948.

De Nieuwsgier, 29 November 1948.

De Sumatra Post, 12 March 1927.

Het Dagblad, 28 January 1949.

Het Nieuws van den Dag, 18 February 1928.

Landbouw, No. 21:12, 1949.

Nieuwe Rotterdamsche Courant, 12 October 1922.

Soerabaijasch Handelsblad, 17 December 1941.

Trouw, 10 March 1948. 